\title{
IMPLEMENTASI CORPORATE SOCIAL REONSIBILITY OLEH BADAN USAHA MILIK DAERAH TERHADAP PELESTARIAN LINGKUNGAN DAERAH ALIRAN SUNGAI BENGAWAN SOLO DI KOTA SURAKARTA
}

\author{
AL. Sentot Sudarwanto S., \\ Fakultas Hukum Universitas Sebelas Maret \\ E-mail: dan alsentotsudarwanto@yahoo.com \\ Anjar Sri Ciptorukmi N. \\ Fakultas Hukum Universitas Sebelas Maret \\ E-mail: acnugrah@yahoo.com
}

\begin{abstract}
This research using juridical empiric approach and incorporated as evaluative-descriptive research by using analysis-qualitative methods. We are using primary and secondary source for our research source. We are using proficient and competent informant that work at PDAM and TSTJ. In order to choose our informant, we are using purposive sampling method. We also use interview and literature study in order to gather data for this research. As the conclusion we can assume that implementation of Corporate Social Responsibility of PDAM Surakarta basically already meet the Surakarta's Local Government Regulation No. 1 Year 2004 regarding Amendment of Surakarta local government regulation No. 3 year 1977, Regulation No.5 year 1962, Regulation No, 32 year 2009. On the other hand, TSTJ Surakarta practically haven't done Corporate Social Responsibility. Nevertheless, they have done the internal conservation by doing reforestation program in TSTJ Surakarta area. Revitalization of Local Government-Owned Corporation in Surakarta has been done in order to create Good Corporate Governances Awareness for the manager of the Local Government-Owned Corporation. Regulation No.5 year 1962 need to be revised by accommodating Corporate Social Responsibility and synchronized with regulation No.32 year 1934 regarding local governance.
\end{abstract}

Keywords:Corporate Social responsibility, Local Government-Owned Corporation, Bengawan Solo's Watershed

\section{Abstrak}

Penelitian ini menggunakan pendekatan yuridis empiris dan disusun sebagai suatu penelitian deskriptif-evaluatif dengan menggunakan metode analisis kualitatif. Sumber data yang digunakan baik sumber data primer maupun sekunder. Informan yang digunakan adalah informan yang layak dan kompeten dari PDAM dan TSTJ. Informan dipilih menggunakan teknik purposive sampling. Pengumpulan data menggunakan wawancara dan studi pustaka. Hasil penelitian menunjukkan bahwa implementasi Tanggungjawab Sosial Perusahaan (CSR) dari PDAM secara prinsip telah sesuai dengan Keputusan Pemerintah Kota Surakarta No. 1 Tahun 2004 tentang Perubahan atas Peraturan Daerah Kotamadya Tingkat II Surakarta No. 3 Tahun 1977, UU No. 5 tahun 1962 dan UU No.32 Tahun 2009. Di sisi lain, TSTJ secara spesifik belum melaksanakan (CSR). Namun, TSTJ telah melakukan konservasi internal antara lain dalam bentuk penanaman pohon di wilayah Perusahaan Daerah TSTJ. Revitalisasi BUMD Kota Surakarta harus dilakukan untuk mewujudkan pengelola yang menerapkan prinsip Good Corporate Governance. Undang-Undang Nomor 5 Tahun 1962 tentang Perusahaan Daerah perlu direvisi untuk mengakomodir peraturan tentang CSR yang disinkronkan dengan Undang-Undang Nomor 32 Tahun 2004 tentang Pemerintah Daerah

Kata Kunci: Tanggung Jawab Sosial Perusahaan, Badan Usaha Milik Daerah, revitalisasi.

\section{A. Pendahuluan}

Kegiatan perusahaan secara umum dapat menimbulkan dampak positif dan dampak negatif. Salah satu dampak negatif terjadinya berbagai tragedi lingkungan yang merupakan akibat dari tidak bertanggung jawabnya perusahaan dalam mengelola dan melaksanakan komitmennya dalam berbisnis secara etis, muncul berbagai tuntutan terhadap perusahaan untuk melakukan kewajiban terhadap lingkungan sosial. Komitmen yang dimaksud adalah melakukan tanggung jawab sosial perusahaan (Corporate Social Responsibility/CSR) yang merupakan suatu komitmen berkelanjutan perusahaan dalam bertindak secara etis, memberikan kontribusi bagi perkembangan ekonomi, meningkatkan kualitas tenaga kerja dan lingkungan lokal, maupun memberikan kontribusi terhadap lingkungan sosial pada umumnya. Perusahaan dituntut untuk melaksanakan CSR dalam pelestarian lingkungan hidup untuk menjaga keseimbangan antara kepentingan perusahaan terhadap keberlangsungan lingkungan.

Implementasi Corporate Social... 
Isu mengenai Tanggung Jawab Sosial Perusahaan (Corporate Social Responsibility/CSR) hingga saat ini merupakan isu yang sedang banyak diperbincangkan oleh berbagai aktivis maupun sivitas akademika. Salah satu definisi mengenai CSR yaitu definisi yang dikemukakan oleh The Word Business Council for Sustainable Development (WBCSD), sebuah lembaga internasional yang berdiri tahun 1995. Terkait dengan hal tersebut, CSR didefinisikan sebagai komitmen dunia usaha untuk terus menerus bertindak secara etis, beroperasi secara legal dan berkontribusi untuk peningkatan ekonomi, bersamaan dengan peningkatan kualitas hidup dari karyawan dan keluarganya sekaligus juga peningkatan kualitas komunitas lokal dan masyarakat secara luas.

CSR penting untuk dilakukan oleh perusahaan terutama oleh perusahaan yang kegiatan operasinya menimbulkan dampak negatif bagi masyarakat maupun lingkungan sekitar. CSR tersebut dianggap penting karena pada kenyataannya terdapat perusahaan yang memiliki hubungan yang tidak harmonis dengan masyarakat (konflik) karena masyarakat atau komunitas lokal merasa terganggu dengan aktivitas perusahaan. Akan tetapi, selain terdapat perusahaan yang memiliki hubungan yang tidak harmonis, terdapat pula perusahaan yang memiliki hubungan yang cukup harmonis dengan masyarakat karena perusahaan tersebut telah menerapkan CSR dengan baik. Penerapan CSR tersebut dilakukan sebagai pembuktian dari adanya fenomena tanggung jawab sosial dan lingkungan yang dilakukan oleh perusahaan. Oleh karena itu semua perusahaan baik yang dimiliki oleh pemerintah (Badan Usaha Milik Negara dan Badan Usaha Milik Daerah), maupun perusahaan swasta mempunyai tanggung jawab moral untuk melaksanakan CSR.

\section{B. Metode Penelitian}

Penelitian ini adalah penelitian hukum empiris yang bersifat deskriptif guna memberi gambaran lengkap mengenai apa dasar yang digunakan BUMD dalam CSR pelestarian lingkungan daerah aliran sungai Bengawan Solo. Lokasi dalam penelitian ini adalah Perusahaan-perusahaan Daerah di Surakarta. Lokasi tersebut dipilih karena CSR yang dikaji dalam penelitian ini dilakukan oleh Perusahaan-perusahaan Daerah yang dimiliki Kota Surakarta, yaitu Perusahaan Daerah Air Minum (PDAM) dan Perusahaan Daerah Taman Satwa Taru Jurug (TSTJ). Jenis data yang dipergunakan dalam penelitian ini adalah Data Primer dan data Sekunder. Sumber data primer dalam penelitian ini adalah Perusahaan Daerah yang dimiliki oleh BUMD Surakarta, sementara sumber data sekunder antara lain Undang-Undang Nomor 40 Tahun 2007 tentang Perseroan Terbatas, Undang-Undang Nomor 5 Tahun 1962 tentang Perusahaan Daerah, Undang-Undang Nomor 32 Tahun 2009 tentang Yustisia Vol.1 No.2 Mei - Agustus 2012
Perlindungan dan Pengelolaan Lingkungan Hidup, bahan hukum sekunder berupa buku-buku di bidang hukum yang berhubungan dengan CSR. Teknik pengumpulan data menggunakan Interview (Wawancara) dan Studi Kepustakaan. Teknik analisa data meliputi tiga tahapan, yaitu mereduksi data, menyajikan data, dan menarik kesimpulan dengan verifikasinya. Diantaranya tahap-tahap tersebut dilakukan pembentukan siklus sehingga data yang terkumpul direduksi lalu ditarik sebuah kesimpulan/konklusi. (HB. Sutopo, 2002 : 97 )

\section{Hasil Penelitian dan Pembahasan}

\section{BUMD Dalam bentuk Perusahaan Daerah}

Perusahaan Daerah (PD) adalah badan usaha yang diatur oleh UU. No. 5/1962 tentang Perusahaan Daerah. Namun kemudian UU. No. 5/1962 ini dicabut dengan UU No. 6/1969 tentang Pernyataan Tidak Berlakunya Berbagai Undang-undang dan Peraturan Pemerintah Pengganti Undang-undang, yang ternyata sarnpai saat ini tidak ada penggantinya.

Secara juridis formal, PD adalah satusatunya bentuk perusahaan yang disediakan oleh undang-undang bagi usaha Pemerintah Daerah di wilayah masing-masing. Artinya apabila Pemerintah Daerah ingin meningkatkan pendapatan daerah dengan jalan mendirikan perusahaan, satu-satunya wadah yang tersedia hanyalah melalui Perusahaan Daerah. Perusahaan Daerah pada umumnya merupakan perusahaan yang sebagian atau seluruh modalnya adalah mi!ik Pemda setempat, dengan konsekuensi yuridis struktur perusahaannya berbeda dengan perusahaan pada umumnya.

Secara juridis kedudukan UU No. 5/1962 adalah sejajar dengan UU No.19/1960 tentang Perusahaan Negara yang di dalam konsideransnya menyebutkan UU No. 5/1962. Selanjutnya UU No. 19/1960 tersebut diubah dengan UU No. 9/1969 tentang perubahan Perusahaan Negara yang diubah menjadi 3 (tiga) bentuk Usaha Negara yaitu Perusahaan Jawatan, Perusahaan Umum dan Perusahaan Perseroan, namun demikian undang-undang tersebut tidak menyebutkan konversi bentuk dari Perusahaan Daerah (PD), sekalipun dalam konsideransnya UU No. 5/1962 tentang Perusahaan Daerah tetap dicantumkan. Padahal yang seharusnya dilakukan adalah merubah sekaligus Undang-undang Perusahaan Daerah sama seperti perubahan Undang-undang Perusahaan Negara. Hal ini dapat diasumsikan sebagai penyebab atau kendala pada PD untuk dioptimalkan fungsinya, karena landasan yuridisnya tidak jelas dan mengakibatkan kekosongan hukum dalam pengaturannya. Oleh karena itu dalam penelitian ini dikaji

Implementasi Corporate Social... 
bagaimana privatisasi BUMD dilakukan oleh Pemda Surabaya, apabila terdapat kendala dalam upaya privatisasi tersebut bagaimana mengatasinya dan selanjutnya juga dikaji apakah cara-cara privatisasi yang dilakukan pada BUMN dapat dipakai untuk memajukan PD/BUMD, paling tidak untuk meningkatkan peranan BUMD dalam pembangunan ekonomi daerah/nasional

Perusahaan daerah adalah perusahaan yang didirikan oleh pemerintah daerah yang modalnya sebagian besar/seluruhnya adalah milik pemerintah daerah. Tujuan pendirian perusahaan daerah untuk pengembangan dan pembangunan potensi ekonomi di daerah yang bersangkutan. Contoh perusahaan daerah antara lain: perusahaan air minum (PDAM) dan Bank Pembangunan Daerah (BPD). Badan Usaha Milik Daerah (BUMD) memiliki kedudukan sangat penting dan strategis dalam menunjang pelaksanaan otonomi. Oleh karena itu, BUMD perlu dioptimalkan pengelolaannya agar benar-benar menjadi kekuatan ekonomi yang handal sehingga dapat berperan aktif, baik dalam menjalankan fungsi dan tugasnya maupun sebagai kekuatan perekonomian daerah. Laba dari BUMD diharapkan memberikan kontribusi yang besar terhadap Pendapatan Asli Daerah. Otonomi daerah memberikan konsekuensi yang cukup besar bagi peran Badan Usaha Milik Daerah (BUMD) dalam menopang Pendapatan Asli Daerah (PAD). Sesungguhnya usaha dan kegiatan ekonomi daerah yang bersumber dari BUMD telah berjalan sejak lama sebelum UU tentang otonomi daerah disahkan. Untuk mencapai sasaran tujuan BUMD sebagai salah satu sarana PAD, perlu adanya upaya optimalisasi BUMD yaitu dengan adanya peningkatan profesionalisasi baik dari segi manajemen. sumber daya manusia maupun sarana dan prasarana yang memadai sehingga memiliki kedudukan yang sejajar dengan kekuatan sektor perekonomian lainnya.

\section{Badan Usaha Milik Daerah Dalam Bentuk Perseroan Terbatas}

Bentuk Hukum Badan Usaha Milik Daerah dapat berupa Perusahaan Daerah (PD) atau Perseroan Terbatas (PT). Pengaturan pendirian PT dalam Undang-undang Nomor 40 Tahun 2007 tentang Perseroan Terbatas cukup sederhana, artinya bahwa PT dapat didirikan dengan adanya minimal dua orang yang berjanji, tertuang dalam akta notaris, dengan modal dasar yang seluruhnya terbagi dalam saham, didaftar di pengadilan, kemudian perseroan akan memperoleh status badan hukum pada tanggal diterbitkannya Keputusan Menteri mengenai pengesahan badan hukum

Yustisia Vol.1 No.2 Mei - Agustus 2012
Perseroan, dan terakhir diumumkan dalam Berita Negara.

Dalam Undang-undang Nomor 32 Tahun 2004 ini diatur bahwa Pemerintah Daerah dapat memiliki BUMD yang pembentukan, penggabungan, pelepasan kepemilikan, dan/atau pembubarannya ditetapkan dengan Peraturan Daerah yang berpedoman pada peraturan perundang-undangan. Norma ini bersifat alternatif dan kumulatif. Seperti disebutkan di atas bahwa BUMD dapat berbentuk PD atau PT, sehingga dapat diartikan bahwa PD atau PT yang berstatus BUMD dalam hal pembentukan, penggabungan, pelepasan kepemilikan, dan/atau pembubarannya ditetapkan dengan Peraturan Daerah.

\section{Daerah Aliran Sungai (DAS) Bengawan Solo}

Kawasan Daerah Aliran Sungai telah mengalami degradasi lahan yang sangat mengkhawatirkan bagi kelangsungan daya dukung lingkungan, sehingga mengakibatkan punahnya ekosistem yang ada. Hal ini akibat dari persepsi sebagian masyarakat atau bahkan penentu kebijakan yang menganggap bahwa kawasan di sekitar sungai merupakan unit atau bagian terpisah dari pengelolaan daerah aliran sungai. Hambatan penerapan kawasan DAS sebagai lahan konservasi (pelestarian) sebenarnya terletak pada good will penentu kebijakan, karena aturan pemanfaatan kawasan lindung sudah jelas diatur dalam undangundang tata ruang baik di tingkat pusat maupun daerah. Di samping itu penyebab lainnya adalah kondisi sosial ekonomi masyarakat yang telah terbiasa memanfaatkan kawasan DAS tersebut sebagai lahan bercocok tanam sehingga dapat meningkatkan penghasilan. Kondisi tersebut menjadikan pengelolaan kawasan DAS sebagai lahan konservasi dan sebagai penyangga tangkapan air, terabaikan. Hal ini perlu dicermati kembali prinsip $2 \mathrm{E}$ (Ekonomi-Ekologi), yaitu keberlanjutan berhubungan dengan tingkat kesejahteraan masyarakat dan kesehatan lingkungan.

\section{Kondisi dan Pemanfaatan Kawasan DAS Solo}

Saat ini secara umum kondisi kawasan DAS Sejak tahun 1970-an telah mengalami degradasi DAS berupa lahan gundul tanah kritis, erosi pada lereng-lereng curam baik yang digunakan untuk pertanian maupun untuk penggunaan lain seperti permukiman dan pertambangan (Eddie Effendie, Direktorat Kehutanan dan Konservasi Sumberdaya Air). Kondisi tersebut lebih parah lagi setelah otonomi daerah, dengan keluarnya UndangUndang Nomor 22 Tahun 1999, kemudian

Implementasi Corporate Social... 
disempurnakan dengan Undang-Undang Nomor 32 Tahun 2004 tentang Pemerintahan Daerah karena kawasan DAS bersifat lintas wilayah dan adminitratif sehingga terjadi tumpang tindih kewenangan antara pemerintah pusat, pemerintah propinsi dan pemerintah Kabupaten/Kota. Klaim kewenangan tersebut lebih didorong oleh manfaat ekonomis kawasan tersebut daripada upaya-upaya konservasi sehingga berdampak pada semakin rusaknya kawasan DAS tersebut. Permasalahan yang dihadapi adalah :

a. Di daerah tangkapan air Waduk Gadjah Mungkur telah terjadi erosi cukup berat yang ditandai adanya permunculan batuan induk, erosi parit dan sedimentasi dari 102 Sub DAS di DAS Solo yang meliputi 23 wilayah kabupaten, ada 28 Sub DAS yang memiliki potensi erosi besar. Erosi aktual yang terjadi terkecil adalah 4,72 ton $/ \mathrm{Ha} / \mathrm{th}$ di Sub DAS Precel dan erosi terbesar terjadi di Sub DAS Dengkeng sebesar $195,84 \mathrm{ton} / \mathrm{Ha} / \mathrm{th}$.

b. Daerah tangkapan air antara Gunung Merapi dan Lawu lahannya sangat subur sehingga menyebabkan perkembangan pemukiman dan industri di wilayah ini sangat pesat. Dampak yang terjadi adalah limbah rumah tangga dan limbah pabrik akan mencemari air tanah, koefisien aliran akan meningkat sehingga erosi pun secara potensial meningkat pula.

c. Anak sungai Bengawan Solo di daerah Sragen, Ngawi, di bagian utara berasal dari daerah Pegunungan Kendeng bertipe intermitten (mengalir pada waktu musim hujan) karena daerah tangkapan air tidak terlalu luas tingkat kelulusan batuan rendah (napal), serta curah hujan \pm 2000 $\mathrm{mm} / \mathrm{th}$ dengan bulan kering 5-6 bulan dengan koefisiensi aliran tinggi dan langka air tanah.

d. penggunaan lahan (KPL) untuk mengetahui potensi optimum dari suatu lahan (Beny Harjadi, Jurnal geografi, 2007).

Permasalahan Wilayah Sungai Bengawan Solo: (1) Kemiskinan di hulu (masalah sosial ekonomi); (2) Terjadi penurunan luas hutan di Wilayah Sungai Bengawan Solo sebesar 31,57\%: Th 2005 : 39.910 ha; Th 2007 : 23.888 ha; (3) Terjadi degradasi dasar sungai dan longsor tebing yang mengakibatkan sedimentasi tinggi; (4) Mengakibatkan banjir besar melanda kota-kota di Jawa Tengah dan Jawa Timur antara lain Ponorogo, Solo, Sukoharjo, Sragen, Ngawi, Bojonegoro, Babat, Gresik (Sri Apriatini Soekardi,2008).

Akhir tahun 2008 yang lalu, menjadi akhir tahun yang akan selalu diingat oleh sebagian Yustisia Vol.1 No.2 Mei - Agustus 2012 warga yang berada di sepanjang Daerah Aliran Sungai Bengawan Solo. Hujan yang turun sepanjang malam pada akhir tahun ternyata membawa bencana bagi penduduk yang tinggal di sepanjang Sungai Bengawan Solo membentang dari Provinsi Jawa Tengah sampai Provinsi Jawa Timur. Di Jateng, kerugian banjir terbesar diderita Kabupaten Sragen yang mencapai Rp 232,728 Miliar, diikuti Kota Solo Rp 36,5 miliar, dan Kabupaten Blora Rp 9 Miliar, sedangkan di Jatim, banjir Bengawan Solo menimbulkan kerugian Rp 589,18 Miliar di wilayah Bojonegoro, Lamongan, Tuban, dan Gresik (Kompas, 19 Maret 2009).

Tidak mengherankan apabila kerugian yang ditimbulkan akibat banjir sungai Bengawan Solo pada akhir tahun 2008 sangat besar, mengingat juga keberadaan Daerah Aliran Sungai Bengawan Solo melewati 18 daerah Kabupaten/Kota baik di provinsi Jawa Timur maupun provinsi Jawa Tengah, dimana penduduknya terdiri dari 16.463.997jiwa (http.//cetak.kompas.com/read/xml/2009/02/01/ 01381121/bengawan.solo.meluap.jatengjatim.banjir).

\section{Pelestarian Fungsi Lingkungan Hidup Daerah Aliran Sungai (DAS) Bengawan Solo}

Adapun penjelasan Pasal 1 ayat (1) dan ayat (2) UU 32 Tahun 2009 tentang Perlindungan dan Pengolahan Lingkungan Hidup sebagai berikut:

\section{Pasal 1}

(a) Bahwa Lingkungan hidup adalah kesatuan ruang dengan semua benda, daya, keadaan, dan makhluk hidup, termasuk manusia dan perilakunya, yang mempengaruhi alam itu sendiri, kelangsungan perikehidupan, dan kesejahteraan manusia serta makhluk hidup lain.

(b) Perlindungan dan Pengelolaan Lingkungan Hidup adalah upaya sistematis dan terpadu yang dilakukan untuk melestarikan fungsi lingkungan hidup dan mencegah terjadinya pencemaran dan/atau kerusakan lingkungan hidup yang meliputi perencanaan, pemanfaatan, pengendalian, pemeliharaan, pengawasan, dan penegakan hukum.

UUD 1945 Pasal 28 H mengamanatkan, bahwa lingkungan hidup yang baik dan sehat merupakan hak asasi setiap warga negara Indonesia. Sementara pada bagian lain dalam UUD 1945, juga ditegaskan, bahwa pembangunan ekonomi nasional Implementasi Corporate Social... 66 
diselenggarakan berdasarkan prinsip berkelanjutan dan berwawasan lingkungan. Oleh karena itu, setelah keluarnya UU 32 Tahun 2009 tentang Perlindungan dan Pengolahan Lingkungan Hidup, seluruh warga negara Republik Indonesia ikut berpartisipasi dalam mengimplementasikannya. Urgensi ini semakin terasa ketika kualitas lingkungan hidup yang semakin menurun telah mengancam kelangsungan perikehidupan manusia dan makhluk hidup lainnya. Termasuk di antaranya yang terkait dengan prosesi alami siklus air.

\section{Konsep Bekerjanya Hukum}

Konsepsi operasional tentang bekerjanya hukum dalam masyarakat didasarkan pada dua konsep yang berbeda yaitu konsep tentang ramalan-ramalan mengenai akibat-akibat (prediction of consequences) yang dikemukakan oleh Lundberg dan Lansing tahun 1973 dan konsep Hans Kelsen tentang aspek rangkap dari suatu peraturan hukum. (Ronny Hanitijo Soemitro, 1989: 23)

Berdasarkan konsep Lundberg dan Lansing, serta konsep Hans Kelsen tersebut Robert B. Seidman dan William J. Chambliss menyusun suatu teori bekerjanya hukum di dalam masyarakat. Keberhasilan pelaksanaan suatu peraturan perundang-undangan sangat tergantung banyak faktor. Secara garis besar bekerjanya hukum dalam masyarakat akan ditentukan oleh beberapa faktor utama. Faktorfaktor tersebut dapat (1) Bersifat yuridis normatif (menyangkut pembuatan peraturan perundang-undangannya); (2) Penegakannya (para pihak dan peranan pemerintah) dan (3) Serta faktor yang bersifat yuridis sosiologis (menyangkut pertimbangan ekonomis serta kultur hukum pelaku bisnis). (Suteki, 2008: 34)

Anthony Allotts menjelaskan tentang batasan-batasan dari keefektivan hukum, yaitu ada semacam kesulitan untuk mengukur mutu keefektivan tersebut. Keefektivan dimaksud dalam batas-batas tingkat pelaksanaan normanorma yang sah, terdapat persoalan dalam memutuskan apakah ukuran bagi pelaksanaan yang diizinkan itu seperti juga yang diperintahkan kemampuan yang dilarang. Sumber kelemahan lain yang sama terlihat dalam kurangnya pengawasan dalam pelaksanaan norma-norma yang disebabkan tidak adanya umpan balik yang cukup dalam sistem undang-undang yang sah. (Otje Salaman S, Anton F. Susanto, 2005: 97).

Teori bekerjanya hukum tersebut oleh Chambliss dan Seidman diragakan dalam bagan sebagai berikut: ( Ronny Hanitijo Soemitro, 2005: 26).

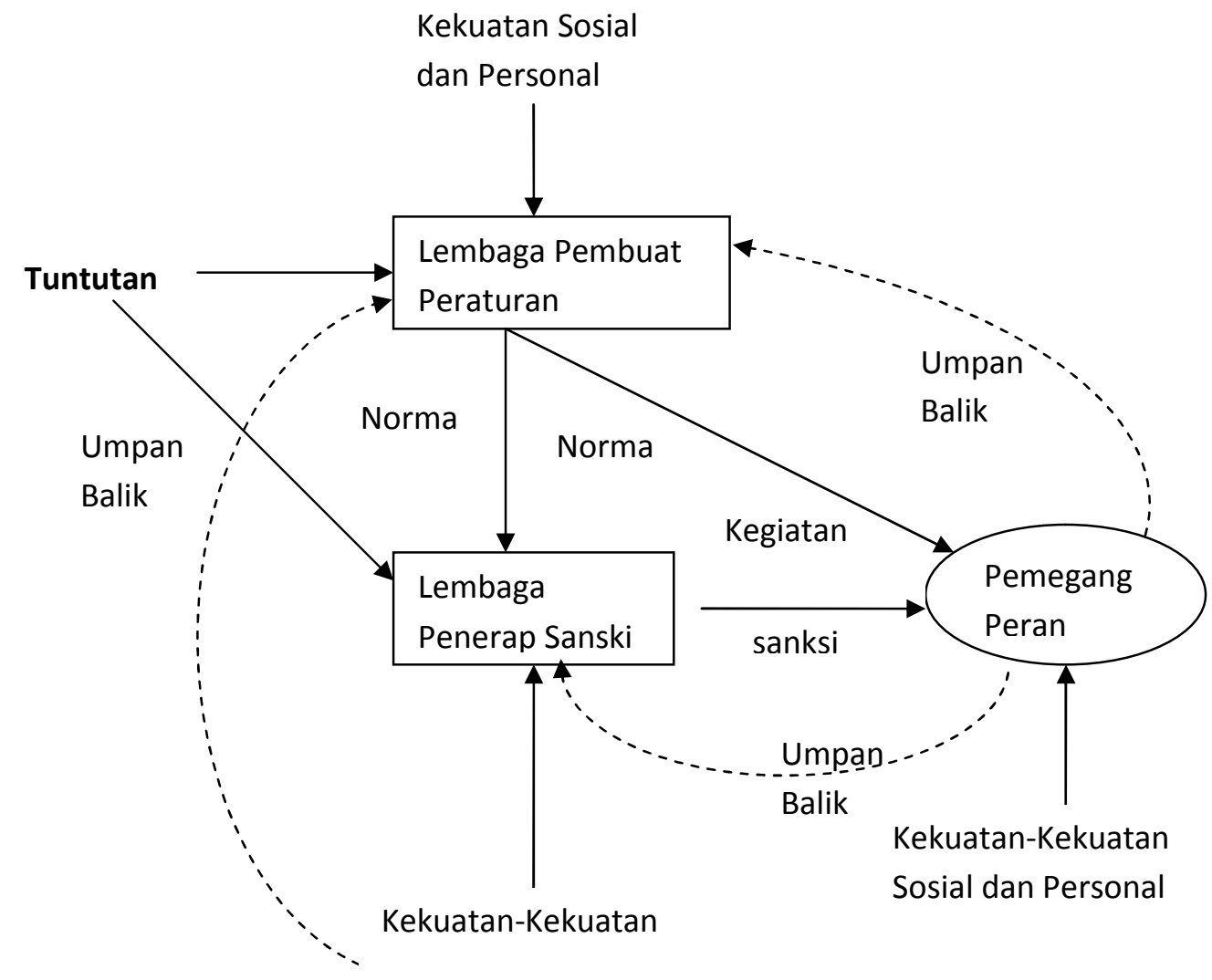


Faktor materi (substansi) suatu hukum atau peraturan perundang-undangan memegang peranan penting dalam penegakan hukum (law enforcement). Artinya di dalam hukum atau peraturan perundang-undangan itu sendiri harus terkandung dan bahkan merupakan conditio sine quanon di dalamnya keadilan (justice). Sebab, bagaimana pun juga hukum yang baik adalah hukum yang di dalamnya terkandung nilai keadilan-keadilan sosial.

7. Pelaksanaan Kegiatan CSR PDAM Kota Surakarta Terhadap Pelestarian Wilayah Daerah Aliran Sungai Bengawan Solo

PDAM Kota Surakarta dalam melaksanakan kegiatan CSR mempunyai beberapa kegiatan pelaksanaan terhadap pelestarian di wilayah daerah aliran sungai Bengawan Solo. Setiap kegiatan pelaksanaan CSR tersebut berbeda sesuai dengan yang dituju. Kegiatan pelaksanaan tersebut antara lain:

\section{a. Penerima Jasa}

Penerima jasa antara lain provinsi Jawa Tengah dan Perum Jasa Tirta I. Pelaksanaan program CSR PDAM Kota Surakarta kepada penerima jasa atas pemanfaatan wilayah daerah aliran sungai Bengawan Solo terdeskripsi seperti di bawah ini :

1) Membayar pajak atas pengambilan dan pemanfaatan air permukaan Bengawan Solo setiap bulannya.

2) Melakukan izin retribusi atas pengambilan dan pemanfaatan air permukaan Bengawan Solo setiap bulannya.

3) Membayar biaya jasa pengelolaan sumber daya air (pemungutan oleh Perum Jasa Tirta I) setiap bulannya.

b. Masyarakat kota Surakarta

Bentuk pelaksanaan program CSR PDAM Kota Surakarta kepada masyarakat Kota Surakarta khususnya warga di sekitar wilayah daerah aliran sungai Bengawan Solo sebagai bentuk pemanfaatan wilayah daerah aliran sungai tersebut, sebagaimana dibawah ini :

1) Pembuatan reservoir (bangunan penampungan air) umum seperti di daerah Pajang, Pasar Kliwon, Semanggi dan lain-lain didarah sekitar Surakarta.

2) Melakukan kegiatan donor darah yang dilakukan oleh PDAM Kota Surakarta.
3) Melakukan pengelolaan limbah cair di daerah Mojosongo dan Semanggi.

4) Membuat forum pelanggan

5) Melakukan pertemuan antara pelanggan $\&$ forum pelanggan

6) Membentuk forum komunikasi di PDAM Kota Surakarta:

a) Forum Komunikasi "forkompamta" di Wilayah Utara Merupakan suatu forum yang membahas tentang ditribusi, kualitas, kuantitas, dan kontinuitas air

b) MPA : Masyarakat Peduli Air Merupakan suatu forum yang dibentuk oleh masyarakat yang peduli dengan air

c) Paguyuban Pengguna PDAM "Tirta Dharma"

Merupakan suatu forum yang membahas tentang ditribusi, kualitas, kuantitas, dan kontinuitas air. Penyuluhan dan Sosialisasi di tingkat RT/RW/Kelurahan di seluruh wilayah Utara Surakarta

\section{c. Lingkungan}

Meliputi kegiatan-kegiatan yang bertujuan memelihara dan melestarikan lingkungan hidup serta melakukan konservasi lingkungan yang ada di wilayah daerah aliran sungai bengawan solo meliputi:

1) Spring Water

Pemanfaatan air di area Merapi lokasi kapasitas $3.404 \quad 1 / \mathrm{dt}$ dimanfaatkan mulai sejak tahun 1980 .

2) Surface Water

Pengolahan air di permukaan, yaitu IPA Jurug dengan kapasitas 100 1/dt.

3) Social Responsibility Mengubah motto "Melayani Lebih Bersih" menjadi "Bersama kami Memulihkan Alam”.pelanggan.Social Responsibility ini dilakukan dengan :

a) Pembuatan Master Plan PDAM Kota Surakarta dengan daerah Kabupaten Boyolali yang memiliki mata air.

b) Meningkatkan Forum Komunikasi PDAM Kota Surakarta dengan penggunaan air lain dan

Implementasi Corporate Social... 
c) Mempelopori dan membiayai pembuatan sumur resapan (recharge) di berbagai wilayah kota Surakarta.

8. Kendala Dalam Pelaksanaan Tanggung Jawab Sosial Oleh Perusahaan Daerah Air Minum Kota Surakarta Beserta Solusinya.

a. Kendala atau Hambatan Dalam Pelaksanaan Tanggung Jawab Sosial Oleh Perusahaan Daerah Air Minum Kota Surakarta

1) Penjualan air yang dilakukan PDAM Kota Surakarta kepada masyarakat kota Surakarta dengan biaya yang tinggi yaitu sekitar Rp. 3.106,00 / $\mathrm{m}^{3}$ sehingga tidak menguntungkan bagi masyarakat miskin dan mengurangi laba perusahaan.

2) Masih adanya kekurangan pemenuhan air bersih kurang lebih 280,43 liter/detik hingga tahun 2011. Kondisi ini memberikan citra buruk dari masyarakat terhadap mutu pelayanan dari PDAM Kota Surakarta.

3) PDAM Kota Surakarta dalam pemenuhan air bersih tidak dapat melakukan pengambilan sumber air dengan membuat sumur-sumur dalam lagi.

4) PDAM Kota Surakarta merupakan Suatu Perusahaan Daerah (Perusda) yang tidak ada pengaturan jelas tentang pengaturan CSR di dalam Undang-Undang Nomor 40 Tahun 2007 tentang Perseroan Terbatas (PT).

b. Solusi Kendala Dalam Pelaksanaan Tanggung Jawab Sosial Oleh Perusahaan Daerah Air Minum Kota Surakarta

1) PDAM Kota Surakarta membuat reservoir Umum (Pembangunan Penampungan Air Umum) di Kota Surakarta yang berjumlah kurang lebih 460 lokasi dengan jumlah layanan 46.000 (1 HU - 100 Jiwa) atau $9 \%$ penduduk kota Surakarta

2) PDAM Kota Surakarta melakukan FRAP (Financial Recovery Action Plan) mulai tahun 2000 yang berisi action plan yang berisi rescheduling hutang tahun 2001.

3) PDAM kota Surakarta melakukan penelitian yang membahas tentang tingkat risiko akibat perubahan bisnis air minum.

4) PDAM Kota Surakarta melakukan penambahan kapasitas IPA (Instalasi Pengolahan Air) di sungai Bengawan Solo di kawasan utara sampai dengan 100 1/det dan pembuatan IPA di

Yustisia Vol.1 No.2 Mei - Agustus 2012 sungai Bengawan Solo kawasan selatan diprediksikan mencapai 300 $1 /$ det.

5) Dikarenakan ketidakjelasan pengaturan pelaksanaan kegiatan CSR PDAM Kota Surakarta maka dalam pelaksanaan kegiatan CSR PDAM berpedoman pada dua peraturan yaitu Peraturan Daerah Kota Surakarta Nomor 1 Tahun 2004 tentang Perubahan Atas Peraturan Daerah Kotamadya Daerah Tingkat II Surakarta Nomor 3 Tahun 1977 tentang Pendirian Perusahaan Daerah Air Minum Kotamadya Daerah Tingkat II Surakarta dan UndangUndang Nomor 5 Tahun 1962 tentang Perusahaan Daerah.

9. Pelestarian Lingkungan Di Wilayah Daerah Aliran Sungai (DAS) Bengawan Solo Oleh Perusahaan Daerah Taman Satwa Taru Jurug (TSTJ)

Berdasarkan hasil penelitian, didapatkan beberapa hal tentang pelestarian lingkungan di wilayah daerah aliran sungai (DAS) Bengawan Solo yang dilakukan oleh Taman Satwa Taru Jurug (TSTJ) adalah sebagai berikut :

a. TSTJ tidak melakukan pembangunan dalam memberikan pelestarian lingkungan di wilayah DAS Bengawan Solo dikarenakan TSTJ tidak memiliki biaya untuk melakukan pembangunan.

b. TSTJ dalam memberikan pelestarian lingkungan di wilayah DAS Bengawan Solo dengan melakukan penanaman pohon seperti pohon trembesi, bringin dan lainlain dengan jarak 30 meter dari bibir sungai.

c. TSTJ dalam memberikan pelestarian lingkungan di wilayah DAS Bengawan Solo bekerjasama dengan para investor untuk melakukan revitalisasi dalam bentuk bangunan, seperti bangunan palung, wahana, kandang binatang dan lain-lain.

d. TSTJ dalam memberikan pelestarian lingkungan di wilayah DAS Bengawan Solo dengan melakukan konservasi terhadap fauna dan flora.

e. TSTJ dalam memberikan pelestarian lingkungan di wilayah DAS Bengawan Solo melakukan larangan terhadap penebangan pohon di sekitar wilayah DAS Bengawan Solo, kecuali pohon tersebut tumbang dikarenakan faktor alam dan pihak TSTJ segera melakukan penanaman kembali / reboisasi.

f. TSTJ dalam memberikan pelestarian lingkungan di wilayah DAS Bengawan Solo dalam hal pengelolaan limbah dibagi

Implementasi Corporate Social... 
beberapa hal tergantung dari jenis limbah

tersebut, antara lain yaitu:

1) Kotoran hewan biasa

Kotoran hewan ini biasanya dicampur dengan sampah kemudian diangkut oleh dinas kebersihan.

2) Kotoran hewan buas

Kotoran ini dikumpulkan kemudian dibuang di sumur resapan yang sudah disediakan oleh pihak TSTJ.

3) Kotoran hewan besar seperti gajah, banteng, kuda dan lain-lain

Kotoran ini dikumpulkan kemudian diolah menjadi pupuk.

4) Seresah (kumpulan daun-daun kering) Daun-daun yang kering dikumpulkan kemudian diolah untuk menjadi pupuk kompos.

g. TSTJ dalam memberikan pelestarian lingkungan di wilayah DAS Bengawan Solo dengan membuat selokan-selokan air dalam bentuk bendungan yang ada di taman satwa tersebut dengan tujuan air tidak hilang atau habis.

10. Kendala Dalam Pelaksanaan Tanggung Jawab Sosial Oleh Perusahaan Daerah Taman Satwa Taru Jurug (TSTJ) Beserta Solusinya.

a. Kendala atau Hambatan Dalam Pelaksanaan Tanggung Jawab Sosial Oleh Perusahaan Daerah Taman Satwa Taru Jurug Kota Surakarta

Management TSTJ yang sebelumnya ditangani oleh Satuan Tugas pemerintahan Kota yang diambil dari Satuan Kerja Perangkat Daerah (SKPD) di Lingkungan Pemerintah Kota. Satuan Tugas yang diambil dari SKPD ini memiliki tugas pokok sebagai pegawai Negeri Sipil (PNS) di samping tugas tambahan sebagai pengelola TSTJ. Hal merupakan kendala pengembangan TSTJ untuk menuju Good Corporate Governance karena para pengelola TSTJ bukan merupakan orang-orang yang berkompeten, yang memiliki jiwa dan keahlian dalam bidang konservasi lingkungan dan memiliki concern pada flora dan fauna. Di samping itu waktu yang disediakan oleh para pimpinan pengelola tidak maksimal dikarenakan tetap berkonsentrasi pada tugas pokok sebagai pejabat PNS.

Pengembangan sebuah usaha tidak akan bisa berkembang tanpa adanya dukungan dana yang memadai. Hal ini terjadi pula pada pengalokasian dana TSTJ Kota Surakarta. Sumber dana untuk pengelolaan TSTJ diambil dari dana Anggaran Pendapatan Belanja
Daerah (APBD) dan hasil tiketing pengunjung TSTJ. Proses pencairan dana APBD dalam pelaksanaannya menemui kendala baik dalam proses maupun jangka waktu. Proses yang sangat prosedural dan waktu yang sulit untuk diprediksi pencairannya, disamping itu hasil pemasukan penjualan tiketing bagi para pengunjung relatif kecil. Sementara kebutuhan untuk pemeliharaan flora dan fauna harus rutin dilakukan.

b. Solusi Kendala Dalam Pelaksanaan Tanggung Jawab Sosial OlehPerusahaan Daerah Air Minum Kota Surakarta

1) Kebijakan Pemerintah Kota Surakarta untuk melakukan perubahan status management dari Satuan Tugas Pengelola TSTJ menjadi Perusahaan Daerah TSTJ Surakarta.

2) Merekrut manajer yang kompeten tidak hanya di bidang konservasi tapi juga di bidang enterpreneurship agar dapat melakukan pengelolaan TSTJ secara profesional dan menerapkan prinsip Good Corporate Governance yang diberi amanat oleh Walikota Surakarta, bahwa dalam waktu satu tahun harus sudah memperlihatkan pengembangan pengelolaan TSTJ Surakarta.

3) Meningkatkan promosi melalui dunia maya (internet) dan event internasional untuk menjaring investor baik dari dalam maupun luar negeri yang memiliki concern di bidang konservasi alam. Pada saat penelitian dilakukan sudah ada 3 (tiga) investor yang mengajukan pengelolaan TSTJ namun akhirnya 2 (dua) investor mengundurkan diri karena tidak adanya titik temu pembagian pengelolaan antara investor dan management TSTJ. Di samping standar kualifikasi yang cukup berat. Standar tersebut meliputi uji kelayakan kelembagaan, management/Sumber Daya Manusia (SDM), keuangan/permodalan, serta masterplanpengembangan TSTJ.

Dari semua persyaratan di atas, syarat yang paling berat untuk dipenuhi investor adalah dari segi finansial yang sebesar 108 miliar Rupiah. Calon investor yang masih bertahan untuk mengikuti lelang adalah PT. Dinamika Karsa Cemerlang. Oleh karena itu Pemerintah Kota dalam hal ini Sekretaris Daerah Kota Surakarta menanggapi mundurnya dua investor mengambil kebijakan untuk beralih

Implementasi Corporate Social... 
dari sistem lelang menjadi penunjukan langsung karena proses lelang sudah terjadi sebanyak dua kali.

4) Menggali potensi kearifan lokal (cerita legenda) yang dikemas dalam bentuk Pesta Budaya dengan tujuan untuk meningkatkan jumlah wisatawan yang datang ke TSTJ sekaligus mengundang investor baru. Salah satu contoh kegiatan Pesta Budaya yang dapat ditampilkan adalah Larung Agung Joko Tingkir (wawancara dengan Direktur Operasional Perusda TSTJ Bapak Windu Winarso, S.H. pada tanggal 5 September 2011 jam 13:00 WIB).

\section{Simpulan}

Berdasarkan hasil penelitian dan pembahasan, maka penulis dapat menarik beberapa kesimpulan adalah sebagai berikut :

1. Tanggung jawab sosial perusahaan BUMD Kota Surakarta terhadap pelestarian lingkungan DAS Bengawan Solo :

a. Pelaksanaan kegiatan tanggung jawab sosial PDAM Kota Surakarta terhadap pelestarian wilayah daerah aliran sungai Bengawan Solo pada prinsipnya telah sesuai dengan Peraturan Daerah Kota Surakarta Nomor 1 Tahun 2004 tentang Perubahan Atas Peraturan Daerah Kotamadya Daerah Tingkat II Surakarta Nomor 3 Tahun 1977 tentang Pendirian Perusahaan Daerah Air Minum Kotamadya Daerah Tingkat II Surakarta, Undang-Undang Nomor 5 Tahun 1962 tentang Perusahaan Daerah, Undang-Undang Nomor 32 Tahun 2009 tentang Perlindungan dan Pengelolaan Lingkungan Hidup.

b. Pelaksanaan tanggung jawab sosial Perusahaan Daerah Air Minum (PDAM) telah mendapatkan dukungan yaitu sumber daya pelaksanaan Kegiatan CSR (sumber daya manusia dan unit pelaksanaan CSR di PDAM Kota Surakarta), dana pelaksanaan kegiatan CSR serta dukungan dari BUMD lain dalam melaksanakan kegiatan CSR kepada masyarakat kota Surakarta.

c. TSTJ secara spesifik belum melaksanakan Corporate Social Responsibility (CSR). Hal ini terlihat dari program-program dan jenis kegiatan Perusahaan Daerah TSTJ, tetapi telah melakukan

Yustisia Vol.1 No.2 Mei - Agustus 2012 konservasi internal antara lain dalam bentuk penanaman pohon di wilayah Perusahaan Daerah TSTJ.

2. Faktor yang menghambat implementasi CSR oleh BUMD terhadap pelestarian lingkungan DAS Bengawan Solo dan solusinya.

a. Faktor penghambat yang dihadapi oleh PDAM Kota Surakarta dalam pelaksanaan kegiatan CSR, yaitu (1) PDAM Kota Surakarta memiliki hutang kurang lebih 37 Milyar yang disebabkan kenaikan nilai pendapatan air dan non air pada tahun 2001 yang secara psychologist air bersih Surakarta menembus angka Rp. 1,00 /liter (tarif rata-rata saat itu Rp. 1.900,00 $/ \mathrm{m}^{3}$ ), (2) Penjualan air yang dilakukan PDAM Kota Surakarta kepada masyarakat kota Surakarta dengan biaya yang tinggi yaitu sekitar Rp. 3.106,00 // $\mathrm{m}^{3}$ sehingga tidak menguntungkan bagi masyarakat miskin, (3) Kebutuhan air bersih sampai dengan tahun 2011 diprediksikan bahwa masih ada kekurangan pemenuhan air kurang lebih 280,43 liter/detik, (4) PDAM Kota Surakarta dalam pemenuhan air bersih tidak dapat melakukan pengambilan sumber air dengan membuat sumur-sumur dalam lagi, (5) PDAM Kota Surakarta merupakan Suatu Perusahaan Daerah (Perusda) yang tidak ada pengaturan jelas tentang pengaturan CSR di dalam UndangUndang Nomor 40 Tahun 2007 tentang Perseroan Terbatas (PT).

b. Solusi untuk mengatasi hambatan adalah sebagai berikut : (1) PDAM Kota Surakarta membuat Reservoir Umum (Pembangunan Penampungan Air Umum) di Kota Surakarta yang berjumlah kurang lebih 460 lokasi dengan jumlah layanan 46.000 (1 HU - 100 Jiwa) atau $9 \%$ penduduk kota Surakarta (2) Untuk biaya operasional PDAM Kota Surakarta yang minimal atau semakin menipis, Maka PDAM Kota Surakarta melakukan FRAP (Financial Recovery Action Plan) mulai tahun 2000 yang berisi action plan yang telah dilakukan mulai tahun 1989 yaitu berupa Resheduling hutang tahun 2001, (2) PDAM kota Surakarta melakukan penelitian yang membahas tentang Implementasi Corporate Social... 71 
tingkat risiko akibat perubahan bisnis air minum, (3) PDAM Kota Surakarta melakukan penambahan kapasitas IPA (Instalasi Penolahan Air) di sungai Bengawan Solo di kawasan utara sampai dengan 100 1/det dan pembuatan IPA di sungai Bengawan Solo kawasan selatan diprediksikan mencapai 300 1/det, (4) Dalam hal pengaturan pelaksanaan kegiatan CSR PDAM Kota Surakarta yang tidak jelas pengaturannya maka dalam melaksanakan kegiatan CSR berpedoman pada dua peraturan yaitu : Peraturan Daerah Kota Surakarta Nomor 1 Tahun 2004 tentang Perubahan Atas Peraturan Daerah Kotamadya Daerah Tingkat II Surakarta Nomor 3 Tahun 1977 tentang Pendirian Perusahaan Daerah Air Minum Kotamadya Daerah Tingkat II Surakarta dan Undang-Undang Nomor 5 Tahun 1962 tentang Perusahaan Daerah.

\section{E. Saran}

Adapun saran yang diberikan penulis kepada Perusahaan Daerah Air Minum Kota Surakarta dalam mencapai Misi dan Tujuan Kegiatan CSR PDAM Kota Surakarta serta meningkatkan keinginan masyarakat untuk mendapatkan air yang bersih atau air minum, yaitu:

1. Perlu dikembangkannya lagi program CSR oleh PDAM Kota Surakarta yang berupa Hydran umum untuk mencukupi kebutuhan masyarakat miskin yang berada di wilayah Surakarta serta perlu dilakukannya revitalisasi Perusahaan Daerah TSTJ dalam rangka menata dan mengembangkan produk diversifikasi wilayah TSTJ sebagai kawasan ecowisata yang mengedepankan nilai budaya dan prinsip sustainable development (pengembangan berkelanjutan).

2. Perlu direvisinya Undang-Undang Nomor 5 Tahun 1962 tentang Perusahaan Daerah dengan mengakomodir peraturan tentang CSR yang disinkronkan dengan UndangUndang Nomor 32 Tahun 2004 tentang Pemerintah Daerah 


\section{DAFTAR PUSTAKA}

Abdullah Rozali. 2000. Pelaksanaan Otonomi Luas dan Isu Federalisme Sebagai Suatu Alternatif. Jakarta. PT Raja Grafindo Persada.

Al Sentot Sudarwanto. 2009. Menelisik Konsep Tanggung Jawab Sosial Lingkungan (Corporate Social Responsibility) Di Indonesia . Jurnal Ilmiah Lingkungan Hidup Ekosains Vol 1 No 2 Juni 2009. Program Pasca Sarjana Ilmu Lingkungan: Universitas Sebelas Maret.

Amin Widjaja Tunggal. 2007. Corporate Social Responbility (CSR) Konsep dan Kasus. Jakarta. Harvarindo.

Andrews, Colin Mac \& Ichlasul Amal (eds.). 1993. Hubungan Pusat Daerah Dalam Pembangunan. PT Raja Grafindo Persada. Jakarta.

Asdak, C. 1995. Hidrologi dan Pengelolaan Daerah Aliran Sungai. Yogyakarta. Gadjah Mada University Press.

Beria Leimona dan Aunul Fauzi. 2008. CSR dan Pelestarian Lingkungan, Mengelola Dampak : Positif dan Negatif. Jakarta : Yayasan Indonesia Business Links.

Farida and van Noordwijk. 2004. Analisis debit sungai akibat perubahan lahan dan aplikasi model Genriver pada das Way Besai. Sumber jaya (Analysis of changes in river flow in response to land use change and application of the GenRiver model to the Way Besai watershed in Sumberjaya). Journal Article. AGRIVITA 26 (1): 39-47.

Gunawan Widjaja dan Yeremia Ardhi Pratama. 2008. Risiko Hukum dan Bisnis Perusahaan Tanpa CSR. Jakarta : Forum Sahabat.

H.B. Sutopo. 2002. Pengantar Penelitian Kualitatif. Surakarta. Universitas Sebelas Maret Press.

I Nyoman Tjager, dkk. 2003.Corporate Governance: Tantangan dan Kesempatan bagi Komunitas Bisnis Indonesia. Jakarta. PT Prenhallindo.

Norman K. Denzin and Yvonna S, Lincoln. 2009. Hand Book Of Qualitative Research. Yogyakarta. Pustaka Pelajar.

Hadi, Sudharto P. 2009. Manusia dan Lingkungan. Semarang. Badan Penerbit Universitas Diponegoro

Poerwanto. 2010. Corporate Social Responsibility, Menjinakkan Gejolak Sosial di Era Pornografi. Yogyakarta. Pustaka Pelajar.

Rohadi, Tasdiyanto. dkk. 2010. Kearifan Lingkungan Budaya Nusantara. Yogyakarta. Cakra Wacana

Soerjono Soekanto. 2010. Pengantar Penelitian Hukum. Jakarta. UI Press.

Sri Apriatini Soekardi. 2008. Pengendalian Wilayah Sungai (WS) di Pulau Jawa (makalah). Jakarta.

Sulchan Yasyin. 1997. Kamus Lengkap Bahasa Indonesia. Surabaya. Amanah.

Yusuf Wibisono. 2007. Membedah Konsep dan Aplikasi Corporate Social Responbility (CSR). Gresik.

\section{Jurnal dan Internet}

Baskin, J. 2006. 'Corporate Responsibility in Emerging Markets'. Journal of Corporate Citizenship

Birch, D., and Moon, J. 2004. 'Introduction: Corporate Social Responsibiity in Asia'. Journal of Corporate Citizenship.

Frynas, J. G. 2006. 'Corporate Social Responsibility in Emerging Economies'. Journal of Corporate Citizenship. 
Lockett, A., Moon, J. and Visser, W. 2006. 'Corporate Social Responsibility in Management Research: Focus, Nature, Salience, and Sources of Influence’. Journal of Management Studies.

Rugman, A. M. and Verbeke, A. 1998. 'Commentary on 'corporate strategies and environmental regulations: an organizing framework'. Strategic Management Journal.

Welford, R. 2011.'Corporate Social Responsibility and Environmental Management'. John Wiley \& Sons, Ltd. and ERP Environment.

http://adln.lib.unair.ac.id/go.php?id=jiptunair-gdl-res-2000--552bumd\&PHPSESSID=4f5f0ea3906625ad2007331627d4a25a (Adriyani, Wuri. Diakses pada Hari Sabtu tanggal 09 Oktober 2010, Jam Akses 08.30 )

http://www.gomong.com/2010/11/10/7032/nasib-divestasi(Lalu Wira Pria S. Diakses pada Hari Sabtu tanggal 09 Oktober 2010, Jam Akses 09.00 ) 